\title{
Is the UK ready for Jointly Managed Academic Medical Centers?
}

Pressure is growing in Britain for the creation of a new type of medical institute designed to overcome tensions between university medical schools and the National Health Service (NHS) by bringing them together into a coordinated management structure. The need for such an initiative arises from the growing difficulty experienced by many engaged in clinical academic research, namely meeting the competing demands of teaching and research on the one hand, and clinical practice on the other.

A report published last month by the House of Lords Select Committee on Science and Technology, which highlights the threats to both biomedical research and the health service generated by these tensions, suggested that the gap might be bridged through the creation of what it calls "University Hospital NHS Trusts." This concept has now evolved into a proposal for the creation of so-called "Jointly Managed Academic Medical Centres" that the Council of Heads of Medical Schools (CHMS) is planning to discuss with the government.

The idea would be to create a single body to oversee the teaching, research and clinical activities of a clinical academic. At present, medical schools are responsible for the first two aspects of such an individual's work and health service trusts for the third. One advantage of such a joint structure, say its supporters, would be to eliminate differences in the approach to, and evaluation of, biomedical research by universities and health trusts.

The Lords report was itself a response to a report published last year by a task force headed by Sir Rex Richards, a former vicechancellor of the University of Oxford. This warned that research in Britain's medical schools was being squeezed by pressures on faculty members to meet teaching and clinical commitments (Nature Med. 3; 821; 1997). The Lords committee endorsed the Richards report's conclusions. "We are persuaded more than ever that there is a genuine threat to academic medicine in the United Kingdom, and therefore to health care as a whole," the committee says.

The government has already responded to the Richards report's call for closer collaboration between parties responsible for health service and university funding. One example is the recent establishment of a sub-group panel as part of the Department of Health's advisory group on medical education training. This panel is intended to provide a forum for the academic and clin- ical communities to discuss "matters of mutual concern" with senior officials in the department, according to Alan Langlands, chief executive of the NHS.

Stephen Tomlinson, dean of the faculty of medicine, dentistry and nursing at the University of Manchester and executive secretary of the council, believes that the newly-proposed joint centers-which could become independent institutions, run separately from the universities to which they are currently linked-would help ensure that medical schools and health trusts work in co-operation rather than competition. "In research, we are not looking for a totally unified strategy, but a complementary strategy," he says. "Identifying four or five areas of top priority for both sides in their appli-

cation to the government for higher education and NHS research funding would be one way of consolidating the strengths of each organization."

Implementing such changes will not be easy, particularly since there could be fierce rivalries involved in merging organizations which are currently run separately. And the strategy still has to be 'sold' to the university funding councils and the NHS. But with the backing of powerful players such as the House of Lords and the Wellcome Trustand with senior funding council and health service officials said to be listening sympathetically-there is a general feeling that, as Michael Powell, CHMS secretary puts it, "now is the right time to press for action." DAvid Dickson, LoNDON

\section{Paternity testing hits mass marketing}

Playing off doubts in the minds of men and women across the country, a small Houston DNA typing firm called Identigene has launched an aggressive, nationwide direct-to-consumer ad campaign. Starting with billboards in Los Angeles, then taxi cabs in New York City and the Washington D.C. subway system, in case the President needs to call, the company's hotline-1-800-DNA-TYPE--has brought mass marketing to biotechnology.

Unlike most paternity-testing companies whose business comes mostly from government child-support agency contracts, Identigene targets the retail niche. "We've had a number of clients who didn't want to start a legal dispute," says president Caroline Caskey, "but who wanted to know the truth." Customers send buccal swab samples to the Identigene lab for PCR analysis. Results take one week.

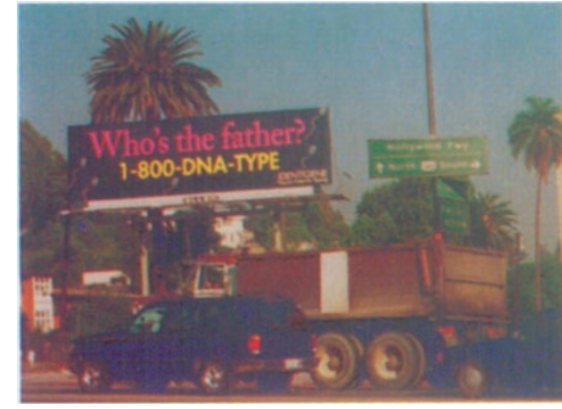

Business is thriving. With 250,000 paternity tests performed in the US each year, private services are an expanding market. ditional alleged father. Identigene also offers forensic studies $(\$ 500)$, marital fidelity studies ( $\$ 500$ per garment sample) and scientific witness testimony at $\$ 1,000$ a day.

KATHLEEN MCGOWAN, NeW YoRK Standard tests are $\$ 600, \$ 200$ for each ad-

\section{Japan catching US in science \& technology}

A special report produced by the Science Resources Studies unit of the US National Science Foundation concludes that Japan has either caught up with, or surpassed, the US in some areas of science and technology. The reason is that Japan now invests more of its GDP in non-defense R\&D than the US, despite its comparatively slower economic growth in the early 90's. However, Japan still lags in competitive research funding at the university level and in producing "influential" scientific articles. These weaker areas are now being addressed through government budgets targeted specifically at university and national laboratories and through an expansion of postdoc-

THE SCIENCE \& TECHNOLOGY RESOUIRCES OF IAPAN: toral programs. The report also reveals that Japan is increasing its support of international research projects, particularly in the field of infectious diseases and the Human Genome Project.

Karen Birmingham, NeW York 